\title{
DHAX Regimen
}

National Cancer Institute

\section{Source}

National Cancer Institute. DHAX Regimen. NCI Thesaurus. Code C159557.

A regimen consisting of dexamethasone, cytarabine and oxaliplatin that can be used to treat relapsed/refractory B-cell non-Hodgkin lymphoma (NHL). 